\title{
Analiza i ocena pakietu legislacyjnego Komisji Europejskiej oraz stanowiska polskiego Ministerstwa Rolnictwa i Rozwoju Wsi dotyczących kształtu Wspólnej Polityki Rolnej Unii Europejskiej po 2013 roku
}

\begin{abstract}
ak słusznie podkreśla polskie Ministerstwo Rolnictwa i Rozwoju Wsi, Wspólna Polityka Rolna (WPR) Unii Europejskiej pełni szczególną rolę w procesie integracji europejskiej oraz w realizacji wielu celów wspólnotowych wykraczających poza tradycyjnie pojmowane funkcje rolnictwa związane z produkcją żywności (np. wielofunkcyjny rozwój terenów wiejskich, ochrona środowiska, globalne wyzwania np. zmiana klimatu, zarządzanie zasobami wodnymi, bioróżnorodność, zdrowie zwierząt i ich dobrostan, bezpieczeństwo żywnościowe i paszowe, zdrowie roślin, zdrowie ludzi oraz interesy konsumentów). WPR odegrała też główną rolę w procesie rozszerzenia Unii Europejskiej o dwanaście nowych państw z Europy Środkowej i Wschodniej, warunkując ich płynne włączenie w Jednolity Rynek, a także umożliwiając przyspieszenie procesów dostosowawczych, modernizacyjnych, restrukturyzacyjnych w sektorze rolno-spożywczym. W ciągu pierwszych lat członkowstwa Polski w UE, Wspólna Polityka Rolna wniosła również duży wkład w aktywizację ekonomiczną i społeczną obszarów wiejskich oraz poprawę spójności ekonomicznej i społecznej w rozszerzonej do 27 państw Unii ${ }^{1}$.

Wejście Polski do Unii Europejskiej stanowiło poważny impuls rozwojowy zarówno dla polskiego rolnictwa, jak i terenów wiejskich, przyspieszając ich rozwój, stopniowo eliminując wielowymiarową, liczoną na 30-40 lat lukę cywilizacyjną względem innych państw tzw. starej Unii (UE-15), jak i w stosunku do terenów miejskich w Polsce. Wieś - co uznać należy za proces właściwy - stopniowo staje się coraz mniej zależna od rolnictwa. Zatrudnionych w polskim rolnictwie jest bowiem o około jeden milion osób mniej niż w połowie lat 90 . minionego wieku. Pozytywne zmiany od lat zachodzą też na obszarach wiejskich, szczególnie powiązanych funkcjonalnie z miastami. Dzięki członkostwu w UE stopniowo poprawia się dostęp wsi polskiej do technologii informatycznych (postępująca internetyzacja wsi i tego następstwa takie jak: e-handel, e-edukacja, e-marketing, e-administracja, telepraca, telemedycyna i sfery pokrewne), jak i innej, tzw. twardej infrastruktury technicznej (szczególnie sieci drogowej, wodociągowej i kanalizacyjnej). Dzięki tzw. suburbanizacji częściowo powstrzymano też procesy depopulacji (wyludniania się) wsi w ramach migracji wewnętrznej do miast oraz poprawiono wskaźniki skolaryzacji mieszkańców terenów wiejskich. Szerszy stał się dostęp do sfery kultury, sportu, rozrywki, rekreacji, a przede wszystkim rozwija się wielofunkcyjność zawodowa mieszkańców terenów wiejskich. Jak wyliczył W. Poczta: ... w per-
\end{abstract}

\footnotetext{
${ }^{1}$ Szerzej zob.: Przyszłość Wspólnej Polityki Rolnej Unii Europejskiej po 2013 roku, Polskie Ministerstwo Rolnictwa i Rozwoju Wsi, Warszawa maj 2009.
} 
spektywie finansowej 2007-2013 polskie rolnictwo uzyska bardzo duże wsparcie w ramach II filara WPR, które średniorocznie wyniesie ponad 1,9 mld euro. Polska z udziałem wynoszacym 13,9\% stanie się zdecydowanie największym beneficjentem tych środków. Łacznie na 2013 rok „przypadnie” dla polskiego rolnictwa prawie 5 mld euro, a polski sektor rolny odnotuje partycypacje $w$ WPR $w$ wysokości $8,4 \%$ i będzie, po rolnictwie francuskim, niemieckim, hiszpańskim $i$ wtoskim, piatym beneficjentem WPR UE. [...] Udziat polskiego rolnictwa $w$ WPR (8,4\%) ulegnie w 2013 roku zbliżeniu do udziału w ogólnej powierzchni użytków rolnych - UR (9,1\%), będzie jednak nadal znacznie mniejszy niż udziat w zatrudnieniu $(18,1 \%)$, ogólnej liczbie gospodarstw rolnych (17,5\%), ale też wyraźnie większy niż udziat polskiego rolnictwa w produkcji $(5,6 \%)^{2}$. Statystycznie odczuwalnie poprawiły się też dochody polskich rolników. Nadal jednak pozostają różnice w dochodach między gospodarstwami domowymi na wsi i w mieście, istotne różnice w poziomie wykształcenia i dostępie do usług użyteczności publicznej (szczególnie żłobki, przedszkola, ale też obiekty sportowe, domy kultury, sfera rekreacji i rozrywki). Wciąż też słabe warunki życia i pracy cechują wsie peryferyjne ${ }^{3}$.

Choćby z tych, wybiórczo wymienionych względów za właściwe uznać należy żywotne zainteresowanie Polski dalszym kształtem Wspólnej Polityki Rolnej Unii Europejskiej po roku 2013. Jak wynika z analiz i raportów opracowanych na zlecenie UKIE (Urzędu Komitetu Integracji Europejskiej), Ministerstwa Rolnictwa i Rozwoju Wsi, Ministerstwa Rozwoju Regionalnego i Ministerstwa Gospodarki Polska na tle innych państw Unii Europejskiej jest krajem, w którym wieś i rolnictwo odgrywają szczególną rolę. Duże zainteresowanie i naturalna troska rządu polskiego o kształt wspólnotowej polityki rolnej i wiejskiej UE po roku 2013 nie powinny więc dziwić. Przeciwnie - są konieczne i w pełni zrozumiałe. Na wsi (około 43 tys. miejscowości wiejskich) mieszka bowiem ponad 38\% ludności polskiej, a obszary wiejskie stanowią ponad $90 \%$ powierzchni naszego kraju. Zatrudnienie w rolnictwie oscyluje wokół

\footnotetext{
${ }^{2}$ W. Poczta, Wspólna Polityka Rolna UE po 2013 roku-uzasadnienie, funkcje, kierunki rozwoju w kontekście interesu polskiego rolnictwa, portal Krajowej Sieci Obszarów Wiejskich: http//www.ksow.gov.pl.

${ }^{3}$ Polska 2030. Wyzwania rozwojowe, Kancelaria Prezesa Rady Ministrów, Warszawa, lipiec 2009, http://www.polska2030.pl.

Dochód polskich rolników wzrósł o 45 proc. w stosunku do 2005 roku - wynika z najnowszych danych z 2011 roku europejskiego urzędu statystycznego Eurostat o przychodach rolników w UE. Polscy rolnicy są wśród tych w Europie, których dochód nie przestaje rosnąć. Polska jest również wśród grupy 11 państw, obok m.in. Wielkiej Brytanii, Niemiec oraz Belgii, w której w ciągu ostatnich pięciu lat dochody na rolnika wzrosły najbardziej. Wyprzedza nas tylko Bułgaria, gdzie dochody rolników wzrosły w porównaniu z 2005 o 58,7 proc. W porównaniu rocznym, między 2009 a 2010, dochód polskich rolników wzrósł o 7,6 proc., głównie dzięki przychodom z dodatkowych zajęć niezwiązanych z produkcją rolną, jak np. agroturystyka (wzrost o 16 proc.). Polacy skorzystali także w dużej mierze ze wzrostu wartości produkcji roślinnej (2,9 proc.) oraz usług rolnych (2,4 proc.). Dopłaty do rolnictwa stanowiły jedną piątą dochodów polskiego rolnika.

W całej UE przychody rolników w 2010 r. wzrosły o ponad 12 proc., w porównaniu z rokiem poprzednim, w którym odnotowano dziesięcioprocentowy spadek w całej UE. Wśród głównych przyczyn zwiększenia dochodów, Eurostat wymienia wzrost wartości produkcji rolnej. Jest on spowodowany prawie całkowicie wzrostem cen produktów rolnych, zarówno roślin, jak i zwierząt. W 2010 r., w skali całej UE, ceny produktów rolnych wzrosły o ponad 5 proc. W górę skoczyły najbardziej ceny nasion oleistych (29 proc.), zbóż (27 proc.) oraz ziemniaków (18 proc.). Wzrosła również nieznacznie wartość usług rolnych (1,3 proc.).

Według danych Eurostatu, do zwiększenia dochodów rolników w Europie przyczynił się także nieprzerwany od 2000 roku spadek cen pracy. W Polsce w 2010 r. koszty pracy w rolnictwie spadły o jedną piątą, czyli tyle samo, co na Łotwie i nieco mniej niż w Bułgarii (-10 proc). Na niezmienionym poziomie pozostała natomiast wartość netto różnych dotacji, z których korzystają unijni rolnicy. W skali UE w 2010 roku wyniosła ona 55 mld 384,9 mln euro, czyli tyle samo, co w roku poprzednim.
}

Zob. Eurostat, Dochód polskich rolników nie przestaje rosnqć, http://www.farmer.pl/PAP, 2.09.2011. 
18 proc. ogółu pracujących, a więc nadal ponad czterokrotnie więcej niż przeciętnie w „UE-15” (tzw. starej Unii). Gospodarstwa rolne są przy tym znacznie mniejsze niż w większości innych państw członkowskich Unii. Choć pełnią one obecnie wiele funkcji w sferze konsumpcji, produkcji rolniczej i pozarolniczej, to jednak wciąż istotnie odbiegają poziomem życia od terenów miejskich i stanowią dość niespójny konglomerat gospodarczy, społeczny i kulturowy. W odniesieniu do rolnictwa należy odnotować, że całkowita powierzchnia użytków rolnych w Polsce wynosi około $15,5 \mathrm{mln}$ ha i zajmuje 52\% całkowitej powierzchni kraju, co plasuje Polskę na szóstym miejscu w Unii Europejskiej. W Polsce w 2010 r. liczba gospodarstw rolnych ogółem wynosiła 2,3 mln, co stanowiło około 17\% z ogółu gospodarstw rolnych całej UE (większa liczba gospodarstw rolnych występuje tylko w zacofanym rolnictwie rumuńskim). Największa liczba gospodarstw miała powierzchnię od 1 do 3 ha (732 tys.), a najmniejsza powyżej 100 ha (9 tys.). Rozdrobnienie polskiego rolnictwa potwierdza także określenie gospodarstw przez ich wielkość ekonomiczną. W ogólnej sumie wszystkich gospodarstw w 2007 r. aż 90\% znajdowało się w grupie do 8 ESU (European Size Unit), przy czym wielkość tę przyjmuje się jako granicę wyznaczającą siłę ekonomiczną gospodarstwa, powyżej której rolnik jest w stanie zapewnić swojej rodzinie godziwy poziom życia oraz reprodukcję majątku produkcyjnego ${ }^{4}$.

Polska wieś z kolei od lat podlega pożądanym ekonomicznie procesom dezagraryzacji, rozumianej jako spadek znaczenia rolnictwa dla gospodarki narodowej i dla społeczności wsi. Ten pożądany proces przebiega jednak znacznie wolniej niż w innych państwach tzw. starej Unii. Regiony wiejskie generalnie rozwijają się wolniej od obszarów miejskich nie tylko zresztą w Polsce. Są mniej atrakcyjne dla inwestorów krajowych i zagranicznych, mają wyższe i trudniejsze do zlikwidowania bezrobocie i relatywnie niewielki kapitał (także społecz-

\footnotetext{
${ }^{4}$ Ibidem.

Ze spisu rolnego z 2010 r. wynika, że od 2002 r. nastąpiły znaczące zmiany w polskim rolnictwie. Spadła liczba gospodarstw o 1/4 - do 2,3 mln, przy tym poprawiła się ich struktura, mniej jest gospodarstw najmniejszych, wzrosła zaś liczba mających powyżej 15 hektarów. Z danych GUS wynika, że 70 proc. polskich gospodarstw ma mniej niż pięć hektarów, tylko 8,6 proc. liczy więcej niż 15 ha. Największych, czyli powyżej 50 ha, jest 27 tys., co stanowi 1,2 proc. W efekcie zachodzących zmian wzrosła średnia wielkość gospodarstw - z ok. 7 ha w 2002 r. do prawie 8 ha w 2010 r. W ciaggu ostatnich ośmiu lat zmniejszyła się powierzchnia użytków rolnych o prawie 8 proc. (o 1,4 mln ha). Obecnie ok. 15,5 mln hektarów wykorzystywanych jest rolniczo. Na większości użytków rolnych - 68 proc. - zasiane są zboża, na 21 proc. znajdują się łąki i pastwiska. Mniej ziemi wykorzystywane jest przy produkcji zbóż. Prawie dwukrotnie zwiększyła się powierzchnia upraw rzepaku. Więcej jest także sadów, jednak ich udział w strukturze upraw jest niewielki i wynosi tylko 2,3 proc.

Jak zaznaczył szef GUS, zmieniła się także struktura hodowli zwierząt. Rolnicy trzymają o 4 proc. więcej bydła, ale o 18 proc. mniej trzody chlewnej oraz o ponad 22 proc. - owiec. W sumie zwiększyło się pogłowie zwierząt przypadających na jedno gospodarstwo specjalistyczne. Zmiany zaszły też w wyposażeniu wsi w maszyny i urządzenia rolnicze. Więcej jest niż w 2002 r. ciągników i kombajnów oraz opryskiwaczy. To efekt zmian w strukturze produkcji rolniczej. Z badania GUS wynika, że w końcu czerwca 2010 r. jeden traktor przypadał na 10,6 ha, podczas gdy w 2002 r. na 12,4 ha. Najnowszy spis wykazał, że w rolnictwie pracuje 2,3 mln osób, z czego zdecydowana większość w gospodarstwach indywidualnych jako tzw. rodzinna siła robocza. W rolnictwie pracuje 14-17 proc. wszystkich zatrudnionych w gospodarce narodowej. Szef GUS podkreślił, że osób, które pracują tylko w gospodarstwach rolnych, jest jedynie 1,95 mln. Natomiast na stałe i dorywczo ogółem pracuje w rolnictwie w ciągu roku ponad 4,5 mln osób.

Por. Od 2002 r. do 2010 r. zmalała o 1/4 liczba gospodarstw rolnych w Polsce, o 8 proc. spadta powierzchnia upraw - poinformował ostatnio p.o. prezesa GUS Janusz Witkowski, za: http://biznes.interia.pl/news/. Szerzej na temat modelu WPR, jego ewolucji w wymiarze regionalnym i globalnym oraz implikacji tego procesu dla polskiego rolnictwa i wsi zob. w: M. Walkowski, Regionalne i globalne uwarunkowania reform Wspólnej Polityki Rolnej Unii Europejskiej, Poznań 2008; Z. W. Puślecki, R. Kmieciak, M. Walkowski, Wspólna Polityka Rolna w warunkach wzrostu konkurencyjności Unii Europejskiej, Warszawa 2010; Rolnictwo polskie we Wspólnej Polityce Rolnej Unii Europejskiej, red. nauk. Z. W. Puślecki, M. Walkowski, Poznań 2004; Rolnictwo polskie w obliczu integracji z Unia Europejska, red. nauk. M. Walkowski, Poznań 1999.
} 
ny). Jednym z czynników wywierających wpływ na konkurencyjność obszarów wiejskich jest też ich lokalizacja. Wsie położone w pobliżu dużych aglomeracji miejskich (tzw. przymetropolitalne) charakteryzują się wyższym poziomem rozwoju niż pozostałe. Coraz słabszą rolę odgrywa tam rolnictwo, a znaczenia nabierają funkcje pozarolnicze - mała i średnia przedsiębiorczość (MSP), handel i rozmaite usługi, częściej przy tym tradycyjne niż z grupy wiedzochłonnych (KIS). Rozwija się mieszkalnictwo (funkcja rezydencjalna), a to przekłada się na relatywnie wyższe dochody tych gmin w porównaniu do dochodów gmin położonych peryferyjnie. Innym rodzajem obszarów, na których następuje przyspieszony rozwój pozarolniczego rynku pracy, są położone wzdłuż głównych ciągów komunikacyjnych, np. dróg ekspresowych i autostrad. Na drugim biegunie znajdują się obszary peryferyjne, które charakteryzują się stagnacją rozwojową oraz ubytkiem ludności (tzw. depopulacja wsi) ${ }^{5}$. Procesy te zauważalne są w zasadzie we wszystkich państwach członkowskich UE. Problem tkwi jednak w tym, że w naszym kraju podział na lepiej rozwiniętą „Polskę miejską” i opóźnioną rozwojowo „Polskę wiejską” jest nadal, pomimo niemal dziesięciu lat członkostwa w UE, zbyt wyrazisty.

Debatę na temat kształtu WPR w nowej perspektywie finansowej 2014-2020 Komisja Europejska (KE) zainicjowała w ramach tzw. Health Check z 2008 roku, wytyczając ogólne kierunki proponowanych zmian. Efektem końcowym dyskusji był pakiet projektów rozporządzeń dotyczących nowego kształtu WPR po 2013 roku, przedstawiony przez KE w dniu 12 października 2011 roku. Był on pochodną rozlicznych i wielowymiarowych konsultacji społecznych z wybranymi grupami interesariuszy, szczególnie dotyczącymi organizacji rolniczych, instytutów naukowo-badawczych/think tanków, jak i szerokiej opinii publicznej. Debatę tą wymusiły nowe okoliczności rozwojowe, w tym: rozmiary i różnorodność Wspólnoty po ostatnich dwóch poszerzeniach z 2004 i 2007 roku; różnice w interesach i stanowiskach państw członkowskich wobec nowego kształtu WPR; nowe priorytety rozwojowe przyjęte w Strategii Lizbońskiej i strategii Europa 2020; presja WTO na dalszą liberalizację handlu rolnego; duża niestabilność na światowych rynkach rolnych pobudzająca dyskusję o bezpieczeństwie żywnościowym w świecie; kryzys gospodarczy i finansowy, który w 2008 roku dotknął cały świat, w tym UE; zmiany preferencji i oczekiwań społecznych w Europie odnoście celów polityki rolnej i wiejskiej w kolejnej dekadzie; presja naukowa i polityczna na rzecz silniejszego niż dotychczas zharmonizowania i zintegrowania WPR z innymi politykami unijnymi i krajowymi ${ }^{6}$. W trakcie konsultacji poprzedzających wydanie oficjalnego komunikatu przez Komisję w 2010 roku dotyczącym perspektyw rozwoju WPR do roku 2020, przeważająca większość państw wyraziła stanowisko, że WPR powinna pozostać silną, ponadnarodową polityką, nadal opierającą się na dwóch filarach, z dominującą rolą dopłat bezpośrednich jako instrumentu wsparcia. Konieczność przekształcenia WPR z typowo sektorowej polityki rolnej w zintegrowaną z innymi politykami wspólnotowymi i krajowymi politykę wspierania obszarów wiejskich też nie budziła większych wątpliwości. Brakuje natomiast zgodności jak procentowo dzielić mają się środki finansowe w ramach dwóch filarów i jakie cele mają one realizować w przyszłości. Różnice stanowisk dotyczyły też systemu płatności bezpośrednich. Przykładowo polscy eksperci podkreślali, że do otrzymywania dopłat uprawnieni powinni być tylko czynni zawodowo rolnicy, zamieszkujący na stałe na obszarach wiejskich. Watpliwości budził też nielimitowany dostęp do dopłat wielkich agrobiznesów i mało efektywne

\footnotetext{
${ }^{5}$ Raport Polska 2011: Gospodarka - Społeczeństwo - Regiony, Ministerstwo Rozwoju Regionalnego, Warszawa, czerwiec 2011.

${ }^{6}$ J. Wilkin, Przyszłość Wspólnej Polityki Rolnej Unii Europejskiej - próba podsumowania dyskusji, „Wieś i Rolnictwo", IRWiR, PAN, Warszawa 2011, nr 1.
} 
wspieranie tą droga gospodarstw marginalnych. Także różnice w wysokości dopłat w państwach UE i sposobach ich wyliczania stanowiły ważny element sporu i polemiki. Ponadto wg badań, WPR po 2013 roku musi utrzymać potencjał w zakresie produkcji żywności na obszarze całej Unii w celu zagwarantowania mieszkańcom Europy długotrwałego bezpieczeństwa żywnościowego (food security). Wspierać ma wspólnoty rolnicze, dostarczające mieszkańcom Europy zróżnicowanej żywności wysokiej jakości, produkowanej w sposób zrównoważony zgodnie z wymogami w zakresie ochrony środowiska, zasobów wodnych, zdrowia i dobrostanu zwierząt, zdrowia roślin, zdrowia publicznego (provision of public goods). Wspomagać i chronić powinna kulturę, tradycje i obyczaje lokalne, czyli dziedzictwo historyczne i tradycyjne życia i pracy na wsi (cultural heritage). Rolnictwo ma też pozostać kluczowym środkiem do zachowania krajobrazu wiejskiego, walki z utratą różnorodności biologicznej oraz przyczyniać się do łagodzenia zmian klimatycznych w świecie (management of natural resources). Ma wnosić większy wkład w walkę z globalnym problemem głodu. W tym wymiarze także pojawia się poważna wątpliwość, sygnalizowana szczególnie przez środowiska naukowe, także polskie. Jak bowiem UE wzmacniać ma swą konkurencyjność produkcji (w tym cenową), zapewniać jej wzrost zapewniający bezpieczeństwo żywnościowe w Europie i w świecie, a jednocześnie ponosić duże koszty związane ze zmniejszaniem presji rolnictwa na środowisko naturalne i szersze niż dotychczas dostarczanie dóbr publicznych? Ewidentnie w rozwiązaniu tym kryje się pewna sprzeczność. Ponadto WPR stanowić też ma podstawę dla dynamicznego rozwoju terenów wiejskich oraz ich długoterminowej efektywności gospodarczej. Powinna też pozostać solidarnie finansowaną polityką wspólnotową, ważnym elementem składowym i następstwem zasad Jednolitego Runku Wewnętrznego UE (The CAP is the corollary of a single market/single economic area) ${ }^{7}$.

Trzy główne cele zreformowanej, dotowanej i nadal - jak założono - ponadnarodowej polityki rolnej i wiejskiej Unii Europejskiej w nowej perspektywie finansowej 2014-2020 (pakiet legislacyjny WPR 2020 proponowany przez KE) to:

\section{Cel 1: Opłacalna produkcja żywności}

- Wsparcie dochodów gospodarstw oraz zmniejszanie ich zmienności, biorąc również pod uwagę, że niestabilność dochodów i cen oraz ryzyka naturalne w omawianym sektorze są bardziej wyraźne niż w innych, a dochody rolników i stopa rentowności są średnio niższe niż w pozostałych sektorach gospodarki.

- Poprawa konkurencyjności sektora rolniczego i wzmocnienie jego udziału jakościowego w łańcuchu żywnościowym, jako że sektor rolniczy charakteryzuje się dużym rozproszeniem w porównaniu z innymi sektorami łańcucha żywnościowego, które są lepiej zorganizowane i dlatego posiadają większą siłę przetargową. Ponadto europejscy rolnicy muszą zmierzyć się z konkurencją ze strony światowych rynków i równocześnie zmuszeni są do przestrzegania wysokich norm związanych z celami w zakresie ochrony środowiska, bezpieczeństwa żywności i jej jakości oraz dobrostanu zwierząt, których wymagają mieszkańcy Europy.

\footnotetext{
${ }^{7}$ The Common Agricultural Policy alter 2013 - Your ideas mattter, Public debate, Summary Report, European Commission, Agriculture and rural Development, EC 2011, http//www.ec.europa.eu oraz komunikat Komisji do Parlamentu Europejskiego, Rady, Europejskiego Komitetu Ekonomiczno-Społecznego i Komitetu Regionów, WPR do 2020 r.: sprostać wyzwaniom przyszłości zwiazanym z żywnościa, zasobami naturalnymi oraz aspektami terytorialnymi, Komisja Europejska, Bruksela, dnia 18.11.2010, KOM(2010) 672 wersja ostateczna; J. Wilkin, Przyszłość Wspólnej Polityki Rolnej Unii Europejskiej - próba podsumowania dyskusji, „Wieś i Rolnictwo”, IRWiR, PAN 2011, nr 1.
} 
- Wynagradzanie za trudności związane z produkcją w obszarach o szczególnych ograniczeniach naturalnych, ponieważ obszary te obarczone są szczególnym ryzykiem zaprzestania działalności rolniczej.

Cel 2: Zrównoważone gospodarowanie zasobami naturalnymi oraz działania na rzecz klimatu

- Zagwarantowanie zrównoważonej działalności produkcyjnej i zabezpieczenie dostarczania środowiskowych dóbr publicznych, ponieważ wiele korzyści czerpanych przez społeczeństwo z rolnictwa nie jest odpowiednio wynagradzanych poprzez normalne funkcjonowanie rynków.

- Promowanie ekologicznego wzrostu poprzez innowacje, co wymaga zastosowania nowych technologii, stworzenia nowych produktów, zmiany procesów produkcyjnych, oraz wspierania nowych wzorów popytu przede wszystkim w kontekście powstającej gospodarki ekologicznej.

- Kontynuacja działań mających na celu łagodzenie skutków zmiany klimatu oraz przystosowania się do nich oraz umożliwienie rolnictwu działań w obliczu zmiany klimatu. Ponieważ rolnictwo jest szczególnie wrażliwe na skutki zmiany klimatu, wspomaganie tego sektora w lepszym dostosowaniu się do efektów ekstremalnych wahań pogody może pomóc zmniejszyć negatywne skutki zmiany klimatu.

\section{Cel 3: Zrównoważony rozwój terytorialny}

- Wspieranie zatrudnienia na obszarach wiejskich oraz wspomaganie zachowania struktur społecznych na obszarach wiejskich.

- Poprawa gospodarki wiejskiej oraz promocja dywersyfikacji, tak aby umożliwić lokalnym podmiotom uwolnienie ich potencjału oraz optymalizację korzystania z lokalnych zasobów.

- Uwzględnienie różnorodności strukturalnej systemów rolniczych, poprawa kondycji małych gospodarstw oraz rozwój lokalnych rynków, ze względu na fakt, iż w Europie zróżnicowane struktury gospodarstw i systemów produkcji przyczyniają się do atrakcyjności i budowania tożsamości regionów wiejskich ${ }^{8}$.

Każde z 27 państw członkowskich UE poproszone zostało o zaprezentowanie krajowych stanowisk w tej sprawie. W opinii rządu polskiego: Wspólna Polityka Rolna także po 2013 r. będzie odgrywać kluczowa rolę w zapewnieniu w UE: bezpieczeństwa żywnościowego, zrównoważonego rozwoju rolnictwa i obszarów wiejskich, równych warunków konkurencji na jednolitym rynku rolnym, a także silnej pozycji konkurencyjnej UE na globalnym rynku rolnym. Z uwagi na wielofunkcyjność rolnictwa i obszarów wiejskich WPR po 2013 r. powinna być tak$\dot{z}$ e efektywnym instrumentem skierowanym na nowe wspólnotowe wyzwania, m.in. zwiazane z ochronq zasobów naturalnych, zmianami klimatycznymi, gospodarkq wodna, różnorodnościa biologicznq oraz energiq odnawialnq. Rzqd RP zwraca uwagę, iz wiele z tych wyzwań ma charakter ponadgraniczny a nawet globalny, co czyni z nich kwestie istotne dla całej Unii, które moga być efektywnie rozwiqzane na poziomie wspólnotowym. Przyszły ksztalt WPR powinien także brać pod uwage skutki ewentualnego porozumienia $w$ ramach DDA WTO dla rolnictwa Unii Europejskiej. [...] Zdaniem Rzadu RP, aby zapewnić skuteczność i efektyw-

\footnotetext{
${ }^{8}$ Ibidem. Zob. również: Komisja przedstawia plan dotyczqcy przyszłości wspólnej polityki rolnej po 2013 r., Bruksela, 18 listopada 2010 r. IP/10/1527, http//www/ec.europa.eu/index_pl.htm.
} 
ność WPR w realizacji powyższych zadań w przyszłości kolejne zmiany tej polityki powinny: zachować w petni jej wspólnotowy charakter, w szczególności w wymiarze finansowym, zapewniajac równe warunki konkurencji na jednolitym rynku UE; powiazać poziom i dystrybucje wsparcia finansowego poszczególnych działań, w tym, w zakresie wsparcia bezpośredniego z aktualnymi i przyszlymi celami, co m.in. wymaga odejścia od historycznych pułapów (kopert) płatności bezpośrednich odzwierciedlajacych intensywność i poziom produkcji rolnej w poszczególnych państwach członkowskich sprzed kilkunastu lat, a także ograniczyć koszty wdrożeniowe zarówno po stronie instytucji UE, państw członkowskich, jak i samych beneficjentów, co wymaga dalszego uproszczenia tej polityki. Przyszła WPR musi być zrozumiała dla rolników, a także dla podatników i bez jej radykalnego uproszczenia nie będzie to możliwe. [...] Zważywszy na: rozszerzenie zakresu celów WPR o nowe wspólnotowe wyzwania, przy zachowaniu większości dotychczas realizowanych zadań; kluczowa rolę solidarności finansowej dla sprawnego funkcjonowania Jednolitego Rynku, a także zmniejszenie poziomu wsparcia cenowego, Rzqd RP podkreśla konieczność zapewnienia odpowiedniego poziomu finansowania wspólnotowego tej polityki po 2013 r. - co najmniej na obecnym poziomie. Jednocześnie Rzq̨ RP wyraża przekonanie, iż istotnym zagrożeniem dla dostarczania europejskiej wartości dodanej przez WPR w przyszłości byłoby zwiększenie współfinansowania tej polityki z budżetów krajowych, a w szczególności wprowadzenie wspólfinansowania krajowego płatności bezpośrednich. Zmiana taka zahamowałaby proces spójności gospodarczej we Wspólnocie, zmuszają biedniejsze państwa członkowskie do zwiększenia wydatków publicznych na zapewnienie równych warunków konkurencji dla swojego sektora rolnego na jednolitym rynku, lub też do rezygnacji z korzyści ekonomicznych zwiazanych z konkurowaniem na równych zasadach w tym sektorze. Próby denacjonalizacji WPR zdaniem Rząu RP sq niedopuszczalne. [...] Biorqc pod uwage powyższe uwarunkowania, zdaniem Rzqdu $R P$, zasadne jest także zachowanie dotychczasowej struktury WPR, tj. wszystkich trzech elementów obecnej polityki: wspólnej organizacji rynków; systemu płatności bezpośrednich oraz polityki rozwoju obszarów wiejskich. [...] Rzqd RP stoi na stanowisku, iż system płatności bezpośrednich wymaga pilnej zmiany polegajacej na jego dalszym uproszeniu i ujednoliceniu formy stosowania w całej UE. [...] W opinii Rzadu RP konieczne jest odejście od obecnych rozwiazań, w których wysokość płatności (stawka SAPS lub średnia wartość uprawnień w SPS) i pułapy (koperty) krajowe odzwierciedlaja historyczne poziomy i intensywność produkcji w poszczególnych państwach członkowskich sprzed kilkunastu lat. Nowy system płatności powinien być zwiqzany z powierzchniq użytków rolnych (uproszczony obecny system SAPS), uwzględniać realizację wymogów w zakresie ochrony środowiska i dodatkowe wsparcie finansowe dla obszarów o niekorzystnych warunkach gospodarowania. Zdaniem Rzqdu RP system polegajacy na jednolitej stawce powierzchniowej w całej UE (flat-rate) lepiej stużyby realizacji obecnych i przyszłych celów WPR niż system dzisiejszy ${ }^{9}$.

Ważny wątek dyskusji nad przyszłością polityki rolnej i wiejskiej w UE stanowiła liczba filarów Wspólnej Polityki Rolnej oraz problem wysokości i systemu podziału dopłat (płatności) bezpośrednich. Debata nad przyszłością WPR na poziomie instrumentarium dotyczyła zwłaszcza płatności bezpośrednich, jako że stanowią najważniejszą pozycję po stronie wydatków na politykę rolną Unii. System płatności bezpośrednich poddawany jest krytyce głównie ze względu na obowiązujący system ich redystrybucji, w wyniku którego na dopłatach korzy-

${ }^{9}$ Stanowisko Rzq̨du Rzeczypospolitej Polskiej w sprawie przyszłości Wspólnej Polityki Rolnej Unii Europejskiej po 2013 roku, dokument rządowy dostępny na stronach internetowych: http//minrol.gov.pl. 
stają w największym stopniu najzamożniejsi rolnicy lub „nie-rolnicy”, będący latyfundystami. Jednocześnie, jeżeli płatności trafiają jak w przypadku Polski, do małych, marginalnych gospodarstw rolnych, są krytykowane jako typowo socjalne, nieefektywne modernizacyjnie wsparcie. Wątpliwości budzi także sposób ustalania krajowych kopert dopłat na zasadzie historycznej, czyli na danych sprzed dekady, preferujących intensywne, niszczące dla środowiska przemysłowe rolnictwo, a także zróżnicowanie wielkości stawek dopłat (różnice między nowymi państwami członkowskimi Unii a „UE-15” oraz samymi gospodarstwami). Ponadto, kwestionowano zasadność tego instrumentu jako wsparcia dochodowego wybranej, jakoby uprzywilejowanej grupy społecznej i zawodowej. W odpowiedzi na tego typu krytykę poszukiwano w Unii nowego uzasadnienia dla stosowania dopłat i nowego sposobu ich konstrukcji.

Polska koncepcja zmian w modelu WPR odnosiła się głównie do instrumentu płatności bezpośrednich i była rozwinięciem uproszczonego systemu płatności bezpośrednich SAPS stosowanego w nowych państwach członkowskich Unii. Płatność obszarowa miałaby być utrzymana we wszystkich państwach na tym samym poziomie, przy czym polska propozycja nie przesądzała na jakim. Miałaby objąć wszystkich rolników, wobec których stosowana jest zasada „cross compliance” (współzależności). W efekcie zastosowania takiego systemu uzyskanoby, w opinii MRiRW, większą spójność między celami instrumentu a alokacją środków, niż ma to miejsce w obecnie wdrażanym systemie opartym na wskaźnikach historycznych. System ,flat rate” (płaska stawka płatności, mająca teoretycznie wiele zalet) popularyzowany przez Polskę był nawet dość poważnie brany pod uwagę przez KE jako właściwy kierunek reformy systemu płatności bezpośrednich. Krytykowano go jednak m.in. za zbyt duże zmiany w alokacjach finansowych między państwami członkowskimi i w efekcie zbyt trudny politycznie do przyjęcia przez 27 państw członkowskich Unii ${ }^{10}$.

Ówczesny minister rolnictwa M. Sawicki wielokrotnie podkreślał, że Polska chce, aby wspólnotowy budżet pozostał co najmniej na dotychczasowym poziomie (tj. z lat 2007-2013). Za najważniejszą sprawę uznał przy tym uproszczenie systemu dopłat i wyrównanie poziomu płatności we wszystkich państwach Unii. Polska chciała, aby dopłaty bezpośrednie w całej UE były powiązane z wielkością gruntów. W naszej projekcji konieczne było także zniesienie historycznych pułapów płatności bezpośrednich, które odzwierciedlają intensywności i poziom produkcji w poszczególnych państwach członkowskich sprzed kilkunastu lat. W tzw. starej UE dopłaty dla rolników nadal częściowo zależą bowiem od wielkości produkcji. Przykładowo we Francji gospodarstwa otrzymują ponad 20 tys. euro z tego tytułu, a jedno na dziesięć z nich 50 tys. euro i więcej. Dotychczasowa polityka rolna dzieli rolników na tych ze starej i nowej Europy [...]. Jeśli dziś Łotwa, liczqc oba filary wsparcia, uzyskuje około 114 euro na hektar, a Grecja powyżej 600 euro, to nikt mi nie wyttumaczy, że nie sq to źródła

\footnotetext{
${ }^{10}$ Ibidem.

W celu finansowego wsparcia rolników, Unia Europejska w latach 90. ubiegłego wieku wprowadziła system płatności bezpośrednich (direct compensatory payments). Płatności pierwotnie miały rekompensować straty związane z obniżką cen skupu na określone produkty rolne. Obecnie jest to najpopularniejsza forma pomocy w produkcji dla rolników w UE. Płatności bezpośrednie dla rolników służą wzmocnieniu konkurencyjności gospodarstw rolnych oraz modernizacji ich gospodarstw. Polska zdecydowała się wprowadzić uproszczony system wypłaty płatności bezpośrednich (SAPS) poprzez zastosowanie jednolitej płatności obszarowej, co jest rozwiązaniem nowym, dotychczas niestosowanym w państwach UE-15. Płatności są wypłacane na hektar, na wszystkie grunty rolne i użytki zielone, utrzymane w dobrej kulturze rolnej, z zachowaniem wymogów ochrony środowiska. System jednolitej płatności obszarowej daje rolnikom większą swobodę wyboru kierunku produkcji, a tym samym zapewnia lepszą efektywność wykorzystania zasobów produkcyjnych. Zastosowanie tego rozwiązania ułatwiło rolnikom prawidłową rejestrację i powszechny udział w systemie, a administracji dotrzymanie napiętych terminów i unijnych wymagań dotyczących realizacji płatności (co było trudne z uwagi na dużą liczbę gospodarstw rolnych).
} 
zakłóceń konkurencyjności - akcentował polski minister. Wśród państw członkowskich UE „rozumiejących polską argumentację” wymieniał on (abstrahując od tego czy słusznie) Portugalię, Danię i Austrię. Dopłaty - wg Polski - powinny być także uzupełnione o rekompensatę dla gospodarstw na obszarach o niekorzystnych warunkach gospodarowania (ONW) oraz niektórych cennych przyrodniczo. Zdaniem ministra Sawickiego WPR powinna być prowadzona w trzech obszarach: dopłat bezpośrednich, rozwoju obszarów wiejskich oraz regulacji rynkowych ${ }^{11}$.

Komisja Europejska - po serii rozmaitych konsultacji na poziomie wspólnotowym i międzyrządowym - przyjęła - jak wspomniano - na początku października 2011 roku projekt reformy Wspólnej Polityki Rolnej na lata 2014-2020. Obiecano przy tym, że odnowiona WPR będzie bardziej przyjazna środowisku, mniej uciążliwa administracyjnie dla małych gospo-

\footnotetext{
${ }^{11}$ Komentarz Ministra Rolnictwa i Rozwoju Wsi do komunikatu KE dotyczqcego WPR po 2013 r., za: http//minrol.gov.pl, 18.11.2010.

Wydaje się, że z obszernego instrumentarium środków dwóch filarów WPR, rolnikom w Polsce najbardziej odpowiadają właśnie dopłaty bezpośrednie. W pewnym sensie trudno się temu dziwić skoro, w samym tylko 2004 roku za posiadanie ziemi polscy rolnicy otrzymali 6,3 mld zł, a w kolejnych latach dopłaty sukcesywnie rosły. W 2005 roku wyniosły już 6,7 mld zl, w 2007 - 8,3 mld zł, a w 2009 - 12,6 mld zł. Teoretycznie nie ma więc w tym nic dziwnego, bowiem trudno nie cieszyć się z dodatkowych i to znacznych środków finansowych. Problem tkwi jednak w tym, że miliardy złotych, które do tej pory z budżetu ogólnego Wspólnot napłynęły do polskiego rolnictwa i na wieś, owszem przyczyniły się, ale nie w należytym stopniu do pożądanych, wręcz niezbędnych zmian strukturalnych w rolnictwie, na wzór tych, które w latach 60., 70. i 80. minionego wieku przechodziły gospodarki rolne państw UE-15. Groźba utrwalania nieefektywnej i archaicznej struktury gospodarstw rolnych w Polsce nadal istnieje i jest poważna. Ponad 90 proc. gospodarstw rolnych w Polsce korzysta z dopłat unijnych. Wiele z nich posiadając hektar, dwa lub trzy otrzymują przeważnie kilkaset, ewentualnie 2-3 tysiące zł (plus dopłaty typu ONW), których nie chcą lub zwyczajnie nie mogą zainwestować w kupno sukcesywnie drożejącej ziemi czy sprzętu rolnego. Prawie 90 proc. rolników uzyskuje rocznie nie więcej niż kilkanaście tysięcy złotych z tytułu dopłat bezpośrednich. Pozostała część dopłat (około 10 proc.), często setki tysięcy, a nawet miliony złotych przypada na duże gospodarstwa towarowe, agrobiznesy lub latyfundia. W małych gospodarstwach socjalnych lub szczątkowo produkujących na rynek gospodarkach niskotowarowych większość pozyskiwanych w ten sposób środków zostaje zwyczajnie skonsumowana. Rolnicy (a raczej warstwa chłopska socjalna) lub tzw. chłopo-robotnicy (stanowiący migrację wahadłową), posiadający ziemię, ale $\mathrm{z}$ reguły pracujący poza rolnictwem, często w pobliskim mieście, kupują za nie telewizory, pralki, kuchenki mikrofalowe i inne dobra trwałej konsumpcji., dokonują większych tygodniowych zakupów w marketach lub odkładają pieniądze na kontach w bankach spółdzielczych. Środki te trafiają więc do ,pseudo-gospodarstw”, o których z góry wiadomo, że nie mają żadnych lub minimalne szanse rozwojowe. Gospodarstw powiększających majątek i modernizujących się jest w naszym kraju zaledwie 15-20 proc. Tylko 340-360 tys. gospodarstw wytwarza żywność i sprzedaje ją na rynek. To właśnie w nich powinna się koncentrować produkcja i to właśnie one, a nie wszystkie zarejestrowane w Polsce w rejestrach GUS powinny być wspierane instrumentami wsparcia dochodowego w ramach WPR. Najbiedniejsze i najmniejsze gospodarstwa socjalne ewidentnie powinny być więc domeną polityki społecznej a nie rolnej! Potencjalnie mogłyby też zostać objęte instrumentami polityki spójności UE. Jak słusznie zauważa W. Poczta w tekście Wspólna Polityka Rolna UE po 2013 roku-uzasadnienie, funkcje, kierunki rozwoju w kontekście interesu polskiego rolnictwa zamieszczonym na portalu Krajowej Sieci Obszarów Wiejskich (http//www.ksow.gov.pl): ...Negatywne doświadczenia, jakie uzyskano przy wdrażaniu i realizacji wsparcia dla gospodarstw niskotowarowych, aż nadto nakazuja podchodzić sceptycznie do zamysłu ich zwiększonego wsparcia. Problem matych gospodarstw jest wtedy aktualny, gdy ich właściciele nie maja możliwości uzyskiwania dodatkowych dochodów spoza rolnictwa. Przyznać przy tym należy, że w najbliższych latach nie ma jednak większych szans, szczególnie przy takich, a nie innych poglądach polskiego MRiRW, aby sytuacja ta uległa zauważalnej zmianie. Z sondażu PBS DGA z 2010 roku wynika, że 54 proc. rolników planuje utrzymanie gospodarstwa na dotychczasowym, często bardzo niskim poziomie, a o rozwoju gospodarstwa myśli zaledwie 24 proc. z nich. W 2010 roku o zmianie jego profilu myślało zaledwie 3 proc. rolników w Polsce. Dlatego cenieni polscy eksperci proponują, aby zmienić sposób wypłacania unijnych pieniędzy, tak żeby rolnicy mieli finansową zachętę do modernizacji i restrukturyzacji gospodarstw. Większe ukierunkowanie funduszy do grup producenckich proponuje np. Wanda Chmielewska-Gill z Fundacji Programów Pomocy dla Rolnictwa (FAPA). Zbliżone opinie formułuje Katarzyna Duczkowska-Małysz z SGH, Jerzy Wilkin z UW czy cytowany już Walenty Poczta z UP w Poznaniu.
} 
darstw, a różnice w dopłatach bezpośrednich między poszczególnymi państwami członkowskimi malejące. Komisarz Dacian Ciolos, prezentując założenia reformy wyjaśniał, że służy ona podniesieniu konkurencyjności europejskiego rolnictwa oraz zapewnieniu bezpieczeństwa żywnościowego Europy, a jednocześnie promocji wysokiej jakości produktów, ochronie środowiska i rozwojowi obszarów wiejskich. Przedstawione propozycje - jak podkreślał - mają na celu jak najlepsze wykorzystanie funduszy poprzez zachęcanie rolników do zwiększania konkurencyjności oraz zagwarantowanie konsumentom dostępu do wysokiej jakości żywności dostępnej po uczciwych cenach.

Przewidziane przez Komisję działania obejmują:

- sprawiedliwsze, prostsze i lepiej ukierunkowane wsparcie - podstawowe wsparcie dochodu będzie dotyczyć jedynie czynnych zawodowo rolników; ma ono zostać ograniczone do 300 tys. euro rocznie na gospodarstwo rolne; fundusze będą sprawiedliwiej rozdzielane między rolników, regiony i państwa UE;

— pomoc dla rolników w podjęciu odpowiednich działań w sytuacji gwałtownych zmian cen i popytu - wsparcie będzie szybciej udzielane w razie kryzysu gospodarczego;

- przeznaczenie 30 proc. płatności bezpośrednich w ramach WPR dla gospodarstw wykorzystujących praktyki przyjazne dla środowiska - wsparcie na rzecz dywersyfikacji upraw, zachowania trwałych użytków zielonych i ochrony środowiska naturalnego i krajobrazów;

- bardziej ukierunkowane badania naukowe i innowacje - podwojenie budżetu na badania naukowe i rozwój, zwiększenie użyteczności badań dla rolników i przyspieszenie transferu wiedzy między środowiskiem naukowym a sektorem rolnym;

— wzmocnienie pozycji rolników - wsparcie organizacji rolniczych oraz promowanie bardziej bezpośrednich kontaktów z konsumentami poprzez ograniczenie liczby pośredników;

— wspieranie ochrony środowiska - walka ze zmianami klimatu i efektywne wykorzystanie zasobów mają stanowić priorytety polityki rozwoju obszarów wiejskich;

— wsparcie dla młodych rolników - wsparcie dla rolników poniżej 40 roku życia będzie udzielane przez pierwsze pięć lat działalności rolniczej;

- promowanie zatrudnienia i ducha przedsiębiorczości na obszarach wiejskich - np. przewidziano wsparcie dla małych projektów z finansowaniem do wysokości 70 tys. euro w ciągu pięciu lat;

— zapobieganie pustynnieniu - udostępnienie dodatkowych środków dla rolników na obszarach o niekorzystnych warunkach naturalnych;

- ograniczenie biurokracji - uproszczenie przepisów, w szczególności dla drobnych rolników, którzy otrzymają płatność zryczałtowaną w wysokości od 500 do 1 tys. euro rocznie na gospodarstwo ${ }^{12}$.

Zgodnie z zaprezentowaną propozycją Komisji, podstawą zreformowanej WPR w nowym wieloletnim budżecie na lata 2013-2020 pozostaną płatności bezpośrednie. Komisja proponuje jednak nowe zasady ich przyznawania. Aż 30 proc. z ogólnej kwoty dopłaty, farmer ma otrzymywać za spełnianie trzech warunków ochrony środowiska: dywersyfikacja kultur rolnych, zabezpieczenie ziemi pod pastwiska oraz poświęcenie 7 proc. upraw na infrastrukturę ekologiczną. Jest to zgodne z ogólną i przyjętą w 2003 roku w Luksemburgu zasadą współza-

${ }^{12}$ Reforma WPR - sprawiedliwe, ekologiczne $i$ wydajne rolnictwo, analiza zawarta na stronach internetowych: $\mathrm{http} / / \mathrm{www}$. ec.europa.eu/news/agriculture, 12.10.2011. 
leżności („,cross-compliance”) pomiędzy uzyskiwaniem dopłat a działaniami ekologicznymi. W sytuacji, w której farmer ww. wymogów nie spełni, otrzyma jedynie pozostałe 70 proc. dopłaty. Przepadła przy tym, głównie za sprawą głównych płatników netto - Niemiec, W. Brytanii, Szwecji, Danii i Holandii (ale też i Francji) propozycja popierana m.in. przez Polskę, a dotycząca jednakowej, równej podstawy dopłat bezpośrednich od hektara we wszystkich państwach Unii. Płatnicy netto (może z wyjątkiem Niemiec, które - pomimo wątpliwości - zazwyczaj jednak popierają Francję) opowiadają się za znaczącym ograniczeniem wydatków na WPR, a nawet jej całkowitą renacjonalizacją. Dlatego też przeforsowanie wartościowo, a nie procentowo naliczanego (uwzględniającego różnice w kosztach produkcji) systemu wyrównywania płatności do hektara wydaje się być bardzo trudne, a w kontekście bieżącego kryzysu gospodarczego w Europie i jego finansowych implikacji wręcz niemożliwe ${ }^{13}$. Propozycja KE zakłada w zamian stopniowe zmniejszanie różnic w tej dziedzinie. Rolnicy w państwach, w których dopłaty wynoszą obecnie poniżej 90 proc. średniej unijnej (271 euro), otrzymają więcej o jedną trzecią różnicy pomiędzy tym, co otrzymują teraz, a 90 proc. średniej w UE. Sytuacja ta dotyczy przede wszystkim państw bałtyckich UE, Rumunii, Portugalii i Słowacji. Pod progiem 90 proc. średniej unijnej dopłat jest też obecnie Polska, czyli dopłaty dla polskich rolników też będą stopniowo rosnać. Powinni oni dostawać w sumie „około 230 euro” na hektar. Zgodnie z propozycją Komisji, Polska w ramach dopłat bezpośrednich powinna otrzymać w 2014 roku (czyli pierwszym roku nowej perspektywy finansowej 2014-2020) 3 mld 38 tys. euro. Z czasem, a konkretnie od 2018 roku kwota ta stopniowo wzrośnie do 3 mld 121 tys. euro rocznie. Farmerzy z państw, które otrzymują obecnie najwyższe dopłaty do hektara, będą stopniowo tracić, ale nie więcej niż 10 proc. sumy wobec obecnych pułapów dopłat. Owo zmniejszanie różnic ma następować stopniowo do 2018 r., ale nawet wówczas nie będzie to oznaczać równych wartościowo poziomów dopłat i identycznego systemu ich naliczania w całej UE-27. Komisarz Ciolos podkreślił co prawda, że obecny system przewiduje inne zasady dla państw UE-15, a inne dla państw UE-12, i nie można go kontynuować po 2013 r., ale zapewniał przy tym, że Komisja wyznaczyła sobie ,polityczny cel", aby problem nierównych dopłat byt rozwiazany w kolejnym budżecie po 2020 roku. Bardziej obiektywne kryteria, zdaniem Komisji potrzebne są również w odniesieniu do przydziału środków w ramach rozwoju obszarów wiejskich, co akurat zgodne jest z polskim punktem widzenia ${ }^{14}$. W Polsce wśród urzędników MRiRW powszechna jest opinia, iż przyszły system płatności bezpośrednich (nawet po roku 2020) nie powinien opierać się na historycznych okresach odniesienia, lecz zostać powiązany z kryteriami obiektywnymi ${ }^{15}$. Zdaniem polskiego ministra Marka Sawickiego reforma WPR powinna być odważniejsza niż wynika to z propozycji Komisji. Oprócz wymienionych założeń, według ustaleń Komisji z października 2011 roku najmniejsze kilkuhektarowe gospodarstwa będą mogły (ale nie musiały!) zamiast tradycyjnych dopłat otrzymywać jednorazowo od 500 do 1 tys. euro rocznie $\mathrm{w}$ ramach tzw. koperty narodowej, co jak przekonuje KE zwolni je z ,niepotrzebnych obciążeń administracyjnych" i kontroli, które teraz muszą spełniać, ubiegając się o tradycyjne

\footnotetext{
${ }^{13}$ Uwarunkowania zmian Wspólnej Polityki Rolnej po roku 2013, FAPA (SAEPR), Warszawa 2011.

${ }^{14}$ Ibidem. Szerzej zob. w: Dacian Cioloş, I want a CAP that is strong, efficient and well-balanced, Conference on public debate entitled 'The CAP after 2013', Brussels, 20 July 2010, SPEECH/10/400, http://www.ec.europa.eu oraz Dacian Cioloş, A new partnership between Europe and its farmers, Speech presenting the legislative proposals on the reform of the Common Agricultural Policy to the European, Parliament, Brussels, 12 October 2011, SPEECH/11/653, http://www.ec.europa.eu.

${ }^{15}$ Komentarz Ministra Rolnictwa i Rozwoju Wsi do komunikatu KE dotyczqcego WPR po 2013 r., za: http//minrol.gov.pl, 18.11.2010.
} 
dopłaty. Inną nowością są zachęty dla rolników młodych (poniżej 40 lat) i rolników dopiero rozpoczynających działalność gospodarczą. Według propozycji Komisji, przez pięć lat mieliby oni obowiązkowo otrzymywać o 25 proc. dopłat więcej niż wynosi średnia krajowa. Warunkiem byłoby posiadanie przynajmniej 25 hektarowego gospodarstwa. Komisja podkreśla, że wspieranie rolnictwa wśród młodych farmerów jest konieczne, bowiem tylko 7 proc. rolników w UE-27 ma mniej niż 40 lat, a aż dwie trzecie ponad 55 lat.

Państwa członkowskie będą też miały swobodę przesunięcia 5 proc. środków między dwoma filarami WPR. To także propozycja zgodna z polskim stanowiskiem negocjacyjnym, ale też zbyt mało radykalna jak na nasze oczekiwania. Minister Sawicki zaapelował bowiem, aby odczuwalnie mniej środków w skali Unii przeznaczać na I filar, czyli głównie dopłaty bezpośrednie dla rolników, a więcej na II filar, czyli rozwój obszarów wiejskich, modernizację gospodarstw i aktywną politykę rozwojową. Europa musi mieć instrument polityki aktywnej i rozwojowej i tym instrumentem powinien być drugi filar. Polityka, w której płaci się 80 proc. środków za bycie rolnikiem, a nie daje się środków na rozwój innowacyjności i budowę konkurencyjności, jest polityka stagnacji. Świat za 20 lat potrzebuje zwiększenia produkcji żywności o 70 proc., a za 40 lat-podwojenia - przekonywał. Przyszły rozwój rolnictwa wymaga wg MRiRW wzmocnienia finansowego II filara w całej UE poprzez ustalenie nowych proporcji pomiędzy alokacją na I i II filar środków z budżetu wspólnotowego dla wszystkich państw członkowskich. W ocenie polskiego ministerstwa podział środków pomiędzy I a II filar WPR powinien wynosić 50:50 lub 60:40, a nie jak dotychczas, średnio 80:20. Zwiększenie środków w ramach II filaru pozwolić miałoby gospodarstwom rolnym na rozwój i modernizację, przyczyniając się do poprawy ich konkurencyjności na rynku światowym. W budżecie WPR na lata 2007-2013 (dwa filary) Polsce przypadało około 24 mld euro. Z propozycji KE i nieoficjalnych obliczeń ekspertów wynika, że w kolejnej siedmioletniej perspektywie Polska może otrzymać nawet około 6 mld euro więcej z tytułu dochodzenia do pełnych płatności bezpośrednich. Komisja przewiduje też, że kwoty mleczne znikną we wrześniu 2016 r., a nie - jak wcześniej planowano - już w 2015 roku. Jest to kolejny, z polskiego punktu widzenia godzien analizy wątek. W opinii Komisji Europejskiej rosnący trend popytowy w świecie na wyroby mleczne, w połączeniu z utrzymaniem kwotowania produkcji mleka w UE będzie pokutować 7,2\% wzrostem cen w latach 2008-2015 (jak obliczono o ok. 1\% rocznie). Brak likwidacji kwot mlecznych oznaczać będzie, że przetwórstwo nie będzie w stanie wykorzystać dobrej koniunktury na swoje produkty na rynku światowym, ani też poprawić swojej konkurencyjności ze względu na ograniczoną ilość surowca. Konsumenci z kolei poniosą stratę ze względu na wysokie ceny produktów. Po uwolnieniu produkcji mleka w 2015 r. produkcja w UE wzrośnie o 3,8\% w stosunku do scenariusza bazowego. W efekcie wzrostu produkcji nastąpi silny spadek cen, średnio o 8,2\%. W przypadku dalszego limitowania (kwotowania) produkcji eksport będzie obniżony, a przetwórstwo będzie wytwarzać produkty wysoko przetworzone. Wzrośnie popyt wewnętrzny i ceny na rynku światowym. Likwidacja kwot poskutkuje stosunkowo dużym wzrostem eksportu i znaczącą obniżką cen światowych, prowadząc do rozwoju sektora mleka. Wzrost produkcji pozwoli na poprawę sytuacji zarówno rolników, jak i przetwórstwa mlecznego, a co za tym idzie będzie miało korzystny wpływ na obszary wiejskie $^{16}$.

${ }^{16}$ Analiza wybranych tematów przedstawionych w komunikacie Komisji Europejskiej: Preparing for the ,, Health Check" of the CAP reform, autorzy: Fundacja Programów Pomocy dla Rolnictwa FAPA, Sekcja Analiz Ekonomicznych Polityki Rolnej - zespół SAEPR, Warszawa, marzec 2008. 
W 2008 roku wszystkie rządy państw unijnych zgodziły się, aby o cenie mleka decydował rynek i jego prawa, a nie urzędnicy i ich regulacje. Rok później zaczęły się jednak gwałtowne protesty zawodowych organizacji rolniczych zrzeszonych w centrali związkowej COPA-COGECA, domagających się od Komisji zdecydowanej interwencji na rynku mleka. Rolnicy protestowali, bowiem w ostatnich kilku miesiącach 2009 roku ceny mleka dramatycznie spadły. Przez lata (zwłaszcza w okresie 2006-2007) farmerzy byli przyzwyczajeni do tego, że mleko drożało, bowiem rosła konsumpcja wewnętrzna, a Chiny i inne kraje regionu azjatyckiego kupowały każdą ilość europejskiego mleka (szczególnie w proszku) oraz serów. Popyt na mleko był tak duży, że kraje Unii zaczęły głośno narzekać na zbyt niskie limity produkcji mleka. Komisja Europejska zaproponowała więc stopniową likwidację kwot produkcji. W 2015 roku - jak pierwotnie planowano - miały one zniknąć całkowicie, a o cenie mleka decydowałoby prawo podaży i popytu. W listopadzie 2008 roku projekt reformy rynku mleka został oficjalnie zaakceptowany przez rządy państw członkowskich Unii. Jednak już w 2009 roku sytuacja diametralnie odwróciła się. Chiny przestały importować mleko, a cena surowca spadła o 30\%. Spadły też ceny produktów mlecznych (mleko w proszku potaniało o 49 proc., ser o 18 proc., a masło o 39 proc.). Sytuację europejskich farmerów pogorszyła jeszcze rosnąca konkurencja ze strony producentów mleka z Nowej Zelandii. W efekcie niektórzy farmerzy w UE stanęli przed widmem bankructwa i rozpoczęli coraz ostrzejsze protesty, którym to Komisja w końcu uległa. Jak przekonywała centrala związkowa COPA-COGECA skupiająca organizacje zawodowe rolników państw Unii Europejskiej, producenci mleka mogli stracić nawet 14 mld euro przed końcem 2009 roku. W krajach należących do unijnej czołówki producentów mleka, takich jak Niemcy czy Holandia, obniżki cen surowca sięgnęły 30 proc. Tylko w pierwszej połowie 2009 roku dochody holenderskich producentów mleka zmniejszyły się o 59\%. W Niemczech co trzeci zakład przetwarzający mleko zagrożony był bankructwem. Coraz większą rolę jako producenci mleka zaczęły odgrywać natomiast takie kraje, jak USA i Brazylia. Globalna produkcja mleka wzrosła, a udział krajów unijnych w światowym eksporcie zauważalnie się zmniejszy ${ }^{17}$. Polska z kolei posiada jedne z najniższych na świecie koszty produkcji mleka. Jednocześnie przyznano jej bardzo restrykcyjne kwoty produkcyjne. Kwotowanie z jednej strony hamuje rozwój najefektywniejszych gospodarstw, z drugiej, chroni producentów najsłabszych. Hamuje ono również nieukończoną restrukturyzację sektora, a wyższe dochody nie zdążyły jeszcze przełożyć się na satysfakcjonującą modernizację gospodarstw. W interesie Polski powinno więc być przede wszystkim, zagwarantowanie odpowiednich warunków dla rozwoju silnego sektora mleczarskiego i dalszej jego modernizacji, czyli docelowa i szybka likwidacja kwot. Natomiast dla gospodarstw mleczarskich w przyszłości niekonkurencyjnych, ważna jest możliwość przekwalifikowania się w kierunkach, na jakie pozwalają im warunki naturalne, np. produkcji zwierzęcej ${ }^{18}$. Propozycja Komisji raczej odzwierciedla jednak obawy niemieckie czy holenderskie, nie jest zgodna z polskim interesem i w ogóle pozostawia pewne wątpliwości co do intencji całkowitej likwidacji kwot mlecznych.

${ }^{17}$ S. Śmigiel, Bieda na europejskiej wsi, „Gazeta Wyborcza”, 9 października 2009. Zob. również: A. Zachariasz, Doptaty rolne większe, ale..., „Gazeta Wyborcza”, 10 stycznia 2012.

${ }^{18}$ Według danych IFCN koszt produkcji $100 \mathrm{~kg}$ mleka w średniej wielkości gospodarstwie w Polsce wynosi 17 dolarów, w gospodarstwie dużym koszty te osiągają do 15 dolarów. Przeciętny koszt produkcji mleka w Unii Europejskiej jest znacznie wyższy i wynosi 28 dolarów na $100 \mathrm{~kg}$ mleka. Na przykład koszty produkcji mleka w Niemczech są dwa razy wyższe (30 USD/100 kg). Według IFCN Polska obok Argentyny i Indii posiada najbardziej konkurencyjny sektor produkcji mleka na świecie, który charakteryzują realne perspektywy wzrostu. 
Z innych ważniejszych elementów warto odnotować, że Komisja zaproponowała także zamrożenie wydatków na WPR w latach 2014-2020 na poziomie z 2013 roku, czyli około 418 mld euro (317 mld euro na I filar, 101 mld euro na II filar). Przewidziała też około 17 mld euro w ramach instrumentów pozabudżetowych, m.in. na sytuacje kryzysowe w sektorze rolnym, fundusz do walki ze skutkami globalizacji czy pomoc żywieniową dla najuboższych. Propozycje Komisji powinny wejść w życie w 2014 r., po zatwierdzeniu przez Parlament Europejski i ministrów poszczególnych państw w Radzie UE ${ }^{19}$.

Podsumowując: należy zauważyć, że październikowa propozycja Komisji Europejskiej z 2011 roku, a dotycząca zmian w modelu WPR w perspektywie finansowej UE 2014-2020 jest zgodna $\mathrm{z}$ polskim interesem narodowym w takim aspekcie jak zachowanie wspólnotowego charakteru WPR opartego na zasadzie solidarności finansowej i zamrożeniu (czyli relatywnym a nie bezwzględnym zmniejszeniu wydatków) na poziomie z 2013 roku. W dobie poważnych problemów finansowych jakie przeżywa aktualnie wiele państw europejskich dotkniętych kryzysem zwanym „2008+” (szczególnie znajdująca się w recesji i dotknięta wysokim bezrobociem grupa PIIGS), poważnej niechęci wielu unijnych płatników netto, z Niemcami na czele, do zwiększania swej składki członkowskiej i wielu pomysłów znacznego ograniczenia wydatków na WPR z budżetu ogólnego Wspólnot (całkowita renacjonalizacja WPR) oraz przeznaczenie w ten sposób zaoszczędzonych środków ich na inne cele rozwojowe (służące poprawie innowacyjności produkcji nakłady na $\mathrm{B}+\mathrm{R}$ ), rozwiązanie to uznać należy za bardzo pożądane z polskiego punktu widzenia. Pozytywnie postrzegać należy także: dodatkowe wsparcie dla młodych rolników (choć już sposób jego wyliczania, skutkujący dużymi różnicami w wysokości dodatkowej premii budzi wątpliwości); uproszczenia administracyjne w dotowaniu mniejszych gospodarstw rolnych, zwolnionych z wymogów wynikających ze stosowania praktyk korzystnych dla klimatu i środowiska (na 9,64 mln gospodarstw o powierzchni poniżej 5 ha w UE aż 5,63 mln zlokalizowanych jest w państwach UE-12); pomysł górnego pułapu (limitu) dopłat dla gospodarstw otrzymujących obecnie ponad 150 tys. euro z tytułu dopłat (w praktyce najczęściej wielkich agrobiznesów); zdefiniowanie i wspieranie jedynie ,aktywnych rolników" co ma istotny walor praktyczny, ale też etyczny, moralny i edukacyjny (w Polsce, w sytuacji gdy 94 proc. gospodarstw otrzymuje $z$ dopłat bezpośrednich nie więcej niż 5 tys. euro rocznie rozwiązanie to dotyczyć będzie tylko nielicznych rolników); dodatkowe środki na rozwój pozarolniczej przedsiębiorczości na terenach wiejskich czy niewielką, ale jednak, możliwość przesunięcia środków z I do II filara WPR. Generalnie w propozycji Komisji cieszyć powinna nas względna równowaga zachowana pomiędzy dotowaniem bezpośrednim rolnictwa, ochroną środowiska naturalnego i niezbędnymi zmianami restrukturyzacyjno-modernizacyjnymi na terenach wiejskich i w samym gospodarstwach. Z drugiej jednak strony, co już w tekście sygnalizowano, tzw. greening (zazielenienie) pierwszego filara WPR (działania na rzecz środowiska i klimatu jako niezbędny element uzyskiwania dopłat bezpośrednich) może oznaczać ograniczenie opłacalności produkcji, a tym samym konkurencyjności cenowej żywności europejskiej. Niemal zupełnie natomiast zignorowany został pomysł ujednolicenia zarówno sposobu obliczania, jak i wysokości dopłat bezpośrednich. Co więcej, poważnych szans w przewidywalnej perspektywie czasowej na wdrożenie systemu $<$ flat rate> w całej UE-27 raczej nie ma. Tak więc nierównomierna, oparta na historycznie określonych zasadach dystrybucja wsparcia dla poszcze-

${ }^{19}$ I. Czerny, Wspólna Polityka Rolna po 2013-bardziej < zielona> i uproszczona, PAP, 12.10.2011 aktualizacja: 2011-10-12 16:00, za: www.wyborcza.biz. Szerzej zob.: The Common Agricultural Policy after 2013. Public debate. Summary Report, European Commission, DGVI, 2011, za: http//www.ec.europa.eu/news/agriculture. 
gólnych państw członkowskich w ramach systemu płatności bezpośrednich, przynajmniej z polskiego punktu widzenia wydaje się być największym mankamentem propozycji Komisji Europejskiej. Zastąpienie dotychczas obowiązujących systemów SPS i SAPS nowym systemem dopłat - BPS (Basic Payment Scheme) też nie jest rozwiązaniem oczekiwanym przez Polskę. Ujednolicenie stawki bazowej dopłat na obszarze całej Wspólnoty mogłoby bowiem zapewnić polskim rolnikom nawet 1 mld euro rocznie więcej niż dotychczas ${ }^{20}$. Z polskiego punktu widzenia przesunięcie o rok daty likwidacji kwot mlecznych, podobnie jak wzmocnienie zasady <cross-compliance $>\mathrm{w}$ dotowaniu produkcji rolnej też niekoniecznie stanowią rozwiązanie optymalne. Bardzo charakterystyczne w omawianej kwestii było stanowisko ministra Sawickiego. Na pytanie dziennikarza: ...czy nowa polityka rolna UE zakłada istnienie gospodarstw, które będa wyłaczone z ogólnej rachunkowości?, stwierdził on: ...trwa dyskusja nad uproszczeniem polityki rolnej. Jednym z rozwiazań, które maja duże poparcie, będzie wprowadzenie zryczałtowanych dopłat bezpośrednich właśnie dla najmniejszych gospodarstw. Zostanq one również zwolnione z uciqżliwych administracyjnych kontroli i obowiqzków wynikajacych z nowego podejścia do ekologii, tzw. zazieleniania. Zgodnie z zamierzeniami Unii każde gospodarstwo tzw. towarowe będzie miało obowiqzek spetniania dodatkowych wymogów środowiskowych, korzystnych z punktu widzenia ochrony klimatu. Moim zdaniem to nie najszczęśliwszy pomyst. Małe gospodarstwa będq uznane z definicji za ,zielone”. Jest tam stosowany płodozmian, używa się niewiele nawozów sztucznych. Najczęściej nie maja wpływu na rynek, stuża wyżywieniu rodziny, która $w$ nim pracuje ${ }^{21}$. Idea wzmocnienia zasady „współzależności” w dotowaniu gospodarstw, z założenia racjonalna w państwach uprzemysłowionych budzi - jak się więc wydaje - słuszną, krytykę ministra kraju znajdującego się na innym, tj. mniej zindustrializowanym poziomie rozwoju, z relatywnie dobrym stanem środowiska naturalnego. Natomiast dalsza, artykułowana przez komisarza rolnego Wspólnot chęć dotowania kilkuhektarowych, marginalnych gospodarstw socjalnych lub niskotowarowych ze środków WPR (a nie na przykład w ramach powiązanej z polityką spójności UE polityki społecznej państwa), której polski rząd się nie sprzeciwia, budzić już może spore wątpliwości. Uzasadnienia ekonomicznego pomysł komisarza D. Ciolosa nie ma bowiem żadnego, ale w Polsce (podobnie zresztą jak w rodzimej dla komisarza Rumunii) pada on na dobry grunt polityczny, związany z utrzymaniem lub zdobyciem dodatkowego elektoratu wyborczego na terenach wiejskich. Nie ma też co liczyć na zapowiadane, odczuwalne uproszczenie WPR po roku 2013. O ile bowiem będzie ono zauważalne w schemacie wsparcia dla małych gospodarstw, o tyle obowiązkowo powiązanie dopłat z działaniami na rzecz środowiska i klimatu grozi jej tylko większym zbiurokratyzowaniem.

Polskie Ministerstwo Rolnictwa i Rozwoju Wsi w swym oficjalnym stanowisku wobec propozycji Komisji dotyczącej przyszłości WPR po roku 2013 akcentuje, nie zawsze przy tym realistycznie - przede wszystkim jej negatywne strony. Zalicza do nich: zbyt mały budżet ogólny UE na ten cel, brak ujednolicenia poziomu stawek dopłat bezpośrednich i potencjalne wycofanie systemu SAPS w nowych państwach członkowskich Unii, częściowe uzależnienie ich wypłat od działań na rzecz środowiska naturalnego i klimatu, odejście od znacznego wzmocnienia finansowego II filaru WPR czy przyjętą definicję ,aktywnego rolnika” (zob. Aneks). WPR po roku 2013 nadal będzie miała wspólnotowy, ponadnarodowy charakter, opierając się na zasadzie solidarności finansowej. Już sam ten fakt, w dobie narastającej, szcze-

${ }^{20}$ M. Zagórski, WPR po 2013 roku-ocena i propozycje modyfikacji, „Wieś i Rolnictwo”, IRWiR, PAN, Warszawa 2012, nr 1.

${ }^{21}$ M. Sawicki, W PSL wymiota nas mtodsi, „Gazeta Wyborcza”, 4 lipca 2012. 
gólnie w czasach bieżącego kryzysu gospodarczego w zintegrowanej Europie, krytyki efektywności polityki rolnej i wiejskiej jako takiej, uznać należy za duży sukces i rozwiązanie dla Polski bardzo korzystne.

\section{Aneks}

\section{„Wstępna ocena najważniejszych założeń pakietu legislacyjnego WPR 2020 \\ z perspektywy Polski" - fragment analizy zawartej na stronie internetowej Ministerstwa Rolnictwa i Rozwoju Wsi: http//www.minrol.gov.pl, Warszawa, 12.10.2011. \\ (Wersja bez zmian autora artykułu)}

Z punktu widzenia Polski oraz prowadzonej debaty publicznej oczekiwaliśmy, że zmiany WPR będą szły w następującym kierunku:

- Zasadniczej reformy WPR - uczynienia jej polityką rozwojową i konkurencyjną wobec rolnictwa z państw pozaeuropejskich, która będzie w stanie odpowiedzieć na rosnące potrzeby żywnościowe Europy i świata w następnych dekadach. Przedstawione dziś propozycje zostały podporządkowane bardziej zasadzie utrzymania transferów budżetowych do państw członkowskich, niż rzeczywistym zmianom w polityce rolnej. Nie uwzględniają one finansowania nowych zadań nałożonych na WPR po jej przeglądzie w 2008 roku.

- Uproszczenia - wszystkie państwa członkowskie jednoznacznie zobowiązały KE do wypracowania propozycji WPR prostych, zrozumiałych dla beneficjentów i podatników. Przedstawione dziś przez KE propozycje są bardzo skomplikowane, idą w kierunku dalszego wzrostu biurokracji i wprowadzają wiele nowych elementów do płatności: konieczność prowadzenia 3 upraw w gospodarstwie - co najmniej 5\% powierzchni i nie więcej niż 70\% powierzchni każda; płatność tylko dla aktywnych rolników - płatności bezpośrednie muszą stanowić więcej niż 5\% przychodów w stosunku do tych z działalności nierolniczej albo na gruntach rolnych składających się na gospodarstwo jest prowadzona minimalna działalność określona przez państwo członkowskie, limity górne płatności (tzw. capping), płatności bezpośrednie wyższe dla młodych rolników, obowiązek zazielenienia 30\% koperty narodowej.

- WPR sprawiedliwej i wyrównanej-drobne korekty finansowe są niewiele warte, wobec nadal utrzymanej koperty narodowej na płatności opartej na historycznych parametrach. Plon referencyjny zbóż czy oleistych sprzed 20 lat oraz pogłowie bydła mięsnego razy 200 euro będą nadal decydować o kopertach finansowych na płatności bezpośrednie w państwach członkowskich. Utrzymanie takich kopert finansowych i następnie, od takiej podstawy, naliczanie procentowe rekompensat za zazielenienie (30\% koperty) lub młodego rolnika (do 2\% koperty), ONW (do 5\% koperty) powoduje pogłębianie nierówności pomiędzy krajami. Państwa o niskich kopertach np. nowe państwa członkowskie, w tym kraje bałtyckie nadal nie będą mogły odpowiednio rekompensować rolnikom obowiązkowych wymagań nałożonych w ramach zazielenienia WPR. Podobnie, z małej koperty krajowej na dopłaty bezpośrednie trudno będzie w jednakowy sposób dopłacać młodym rolnikom w UE. Brak jest propozycji, które gwarantowałyby pełne zrównanie płatności bezpośrednich w całej Wspólnocie. Do końca 2019 r. zrównanie takie miałoby nastąpić jedynie na poziomie regionów/państw członkowskich. [...] 


\section{Ocena ogólna - kwestie najistotniejsze}

Negatywne:

- wprowadzenie nowych, dodatkowych zadań dla WPR (w tym ograniczeń dla praktyk produkcyjnych) z pozostawieniem dotychczasowego poziomu budżetu; prowadzić to będzie do ograniczenia konkurencyjności międzynarodowej rolnictwa UE i przeniesienia części produkcji poza UE, co miałoby negatywne konsekwencje, m.in. środowiskowe;

- niewielki zakres wyrównania wsparcia bezpośredniego pomiędzy państwami członkowskimi i de facto zachowanie (choć zmniejszonego) zróżnicowania stawek opartego o historyczną intensywność produkcji rolnej; Projekt przewiduje jedynie częściowe zmniejszenie dysproporcji w wysokości płatności pomiędzy państwami członkowskimi. Brak jest propozycji, które gwarantowałyby pełne zrównanie płatności bezpośrednich w całej Unii w oparciu o stawki powierzchniowe, co byłoby spójne z polskim postulatem, aby powierzchnia UR była jedynym lub podstawowym kryterium określającym wysokość kopert krajowych (tj. dobrze opisującym potencjał w zakresie produkcji żywności i ochrony środowiska). Do końca 2019 r. zrównanie takie miałoby nastąpić jedynie na poziomie regionów/państw członkowskich; odejście od wzmacniania finansowego filaru II, co było elementem wszystkich dotychczasowych reform WPR, i co dobrze służyło wspieraniu aktywnego rozwoju rolnictwa i obszarów wiejskich UE; przeniesienie niektórych funkcji i działań między filarami oraz nowe komponenty filaru I skutkują zatarciem wyraźnego dziś podziału ról pomiędzy I a II filarem;

— wzrost złożoności WPR, szczególnie w ramach filaru I, m.in. poprzez wyodrębnienie zielonego komponentu płatności, złożone relacje w ramach Dobrej Kultury Rolnej (GAEC), zielonym komponentem filara I a działaniami rolno-środowiskowymi filara II, złożone wymagania programowania i ewaluacji w ROW; objęcie aktami delegowanymi bardzo wielu istotnych kwestii w ramach poszczególnych obszarów WPR, w tym m.in. działań interwencyjnych i regulacji w handlu zagranicznym, co oznacza istotne zwiększenie uprawnień KE i ograniczenie roli Rady w procesie stanowienia prawa rolnego UE; brak na tym etapie znajomości projektów tych aktów (delegowanych, ale także wykonawczych) utrudnia, a czasem uniemożliwia diagnozę i ocenę niektórych elementów propozycji.

Pozytywne:

— poprawa dystrybucji wsparcia bezpośredniego pomiędzy gospodarstwami o różnych wielkościach poprzez mechanizm degresywnej redukcji płatności - dla dużych gospodarstw (capping), oraz wzrost stawek wsparcia jednostkowego - dla małych gospodarstw (efekt zryczałtowanej płatności dla małych gospodarstw);

- wyeksponowanie roli małych gospodarstw w europejskim modelu rolnictwa i dla realizacji celów strategii Europa 2020, w szczególności dotyczących wzrostu zrównoważonego i sprzyjającego włączeniu społecznemu (możliwość tworzenia tematycznych pod-programów w ramach PROW dla małych gospodarstw, zryczałtowana płatność bezpośrednia dla małych gospodarstw, wsparcie dywersyfikacji dochodów w filarze II, instrumenty wzmacniające pozycję rynkową tych gospodarstw);

- rozszerzenie zakresu instrumentarium WPR o działania nowe, uzupełniające w stosunku do obecnych instrumentów, a wychodzące naprzeciw nowym wyzwaniom (np.: nowe instrumenty zarządzania ryzykiem, rozszerzenie zakresu działań: wsparcie dla grup producentów, współpraca, rozszerzenie niektórych działań rynkowych na wszystkie produkty). 
Wymagajace wyjaśnień KE $i$ dalszych analiz:

— dążenie do poprawy skuteczności w zakresie realizacji celów oraz efektywności WPR poprzez: (i) wzmocnienie planowania strategicznego (silne powiązanie programów ze strategią Europa 2020), (ii) silniejszą integrację pomiędzy różnymi instrumentami, a także funduszami UE (w szczególności z polityką spójności) oraz (iii) nakierowanie wsparcia unijnego (w szczególności II filara) na ściśle zdefiniowane, mierzalne cele, zapowiedź systematycznego badania ich realizacji i alokowania dodatkowych środków do programów najlepiej je realizujących (,rezerwa wykonania”) - obecnie brak jasności, czy rezerwa tworzona ma być na szczeblu krajowym, czy unijnym;

— próby zmniejszenia obciążeń administracyjnych, w szczególności dla małych gospodarstw, co jest bardzo istotne dla krajów takich jak Polska np. płatność ryczałtowa dla małych gospodarstw powiązana z wyłączeniem z kontroli zasady wzajemnej zgodności (cross-compliance); niemniej w propozycji legislacyjnej dominują elementy komplikujące WPR;

— możliwość przesunięcia z filaru I do filaru II do 10\% koperty finansowej, a w przypadku państw o stawce płatności poniżej 90\% średniej UE do 5\% z filaru II do filaru I; zwiększa to elastyczność dla państw członkowskich w programowaniu i realizacji zakładanych celów WPR - z jednej strony, jednak z drugiej - prowadzi do różnicowania warunków funkcjonowania sektora w różnych państwach;

— propozycja „przemieszczenia” niektórych rozwiązań między poszczególnymi rozporządzeniami; m.in. umieszczenie zapisów dotyczących doradztwa, zasady wzajemnej zgodności (cross-compliance) w rozporządzeniu ws. finansowania, zarządzania i monitoringu WPR, umieszczenie zapisów dotyczących zarządzania ryzykiem w rozporządzeniu ws. wsparcia rozwoju obszarów wiejskich z EFRROW; takie podejście generuje zarówno korzyści (np.: ułatwienie jednolitego podejścia do spraw kontroli finansowej w obu filarach, ale może także generować utrudnienia wynikające m.in. z rozdzielenia spraw silnie powiązanych merytorycznie (np.: szczegóły dotyczące dobrej kultury rolnej i komponentu zielonego PB);

- nowa koncepcja wdrażania Leader - dopuszczenie realizacji strategii wielofunduszowych stwarza nowe możliwości rozwoju lokalnego. Dalszych wyjaśnień wymaga jednak koncepcja realizacji tego rozwiązania w powiązaniu z regulacjami ogólnymi dotyczącymi polityki spójności.

\section{Platności bezpośrednie}

Negatywne:

— objęcie całej UE systemem płatności opartym na uprawnieniach (jak obecny SPS) i tym samym wycofanie SAPS w nowych Państwach Członkowskich;

— możliwość kontynuowania do 2018 częściowego (do 60\% koperty krajowej) zróżnicowania wsparcia bezpośredniego między gospodarstwami (w państwach członkowskich stosujących SPS) w oparciu o wartości historyczne - pełna regionalizacja płatności, tj. wprowadzenie jednolitej w kraju płatności ma nastąpić dopiero w 2019 r.; do tego czasu gospodarstwa zajmujące się w tych państwach produkcją, np. bydła, będą w uprzywilejowanej sytuacji na rynku UE;

- utworzenie komponentu zielonego w ramach płatności bezpośrednich z przeznaczeniem 30\% koperty krajowej na ten cel; zaproponowany sposób „zazielenienia” nie uwzględnia w pełni efektów środowiskowych osiąganych poprzez obecne instrumenty, takie jak 
działania rolno-środowiskowe II filaru WPR oraz wymogi wzajemnej zgodności, a także potencjału poprawy w tym zakresie; podejście to będzie generować dodatkowe obciążenia administracyjne;

- definicja aktywnego rolnika, definicja zakłada, iż są to rolnicy, których wysokość płatności bezpośrednich rocznie przekracza bądź jest równa 5\% łącznej sumy przychodów z działalności nierolniczej albo na gruntach rolnych składających się na ich gospodarstwa jest prowadzona minimalna działalność określona przez państwo członkowskie (definicja ta nie dotyczy rolników którzy otrzymali poniżej 5 tys. euro);

— brak możliwości stosowania płatności powiązanych z produkcją w sektorze tytoniu;

- brak mechanizmów zapewniających pełne wykorzystanie krajowych kopert finansowych; środki przeznaczone np. na ONW, młodego rolnika, małe gospodarstwa itp., w przypadku niewykorzystania w danym roku powinny być dostępne w ramach podstawowego komponentu płatności; podobnie, w przypadku braku aktywacji uprawnień $\mathrm{w}$ danym roku, uprawnienia takie nie powinny być brane pod uwage przy ustalaniu wartości uprawnień komponentu podstawowego w danym roku.

\section{Pozytywne:}

- możliwość zwiększenia wsparcia dla ONW poprzez dodatkowy, dobrowolny komponent płatności w filarze I (do 5\% koperty, fakultatywnie dla $\mathrm{PCz}$ );

— odejście od podziału norm dobrej kultury rolnej GAEC na dobrowolne i obowiązkowe, co jest jednym z warunków ujednolicenia tych wymogów między państwami członkowskimi;

— utrzymanie i rozszerzenie na inne produkty możliwości powiązania wsparcia z produkcją, do 5\% koperty z możliwością zwiększenia do $10 \%$ dla państw stosujących SAPS w 2013 r. lub innych uzasadnionych przypadkach; niemniej jednak projekt nie daje możliwości takiego wsparcia dla sektora tytoniu.

\section{Rozwój obszarów wiejskich}

Negatywne:

— większe obciążenia administracyjne w zakresie wdrażania II filara WPR, wynikające m.in. z konieczności harmonizacji systemu programowania i wdrażania zarówno z I filarem WPR, jak i innymi funduszami (Wspólne Ramy Strategiczne, Kontrakt Partnerski), warunkowością ex-ante, położeniem nacisku na uzyskiwanie mierzalnych efektów realizacji programów; zmianą poziomu bazowego w przypadku działań dawnej osi II, wdrażanie Leadera w sposób wielofunduszowy, obowiązek utworzenia Europejskiej Sieci ds. Innowacji (EIP) itp. może skutkować bardzo napiętym i trudnym do realizacji harmonogramem programowania wsparcia obszarów wiejskich;

- pozorne uproszczenie dotyczące zmniejszenia liczby działań; część działań, w szczególności działanie inwestycje w aktywa niematerialne, obejmuje swym zakresem kilka dotychczasowych działań;

— wzrost wymagań względem działań rolno-środowiskowych i skomplikowanie całego systemu w związku z wprowadzeniem komponentu zielonego w I filarze (wyższy poziom bazowy zawężający zakres działań i zmniejszający poziom rekompensat);

- nowe, wyłącznie biofizyczne kryteria wyznaczania ONW (wykluczające stosowanie kryterium społecznego, które odpowiada za znaczną część obszarów obecnie określonych jako ONW w Polsce), co może skutkować pewnym ograniczeniem tego obszaru i przesunięciem terytorialnym; 


\section{Pozytywne:}

- utrzymanie zakresu mechanizmów wsparcia finansowego II filara, z pozostawieniem dużej autonomii dla państw członkowskich, a także z uwzględnieniem kryterium spójnościowego w sposobie alokacji budżetu II filara WPR pomiędzy krajami członkowskimi; daje to szanse na utrzymanie obecnej skali finansowej i także dużej części zakresu przedmiotowego obecnego wsparcia w ramach PROW;

— priorytety rozwoju obszarów wiejskich zgodne z obecnie obowiązującymi, przy czym znaczny nacisk położono na kwestie klimatu i innowacyjności;

- wzmocnienie roli programowania strategicznego, dążenie do ukierunkowania pomocy w sposób zapewniający realizację celów wyznaczonych na poziomie UE i państw członkowskich oraz odejście od osi w ramach PROW, co zwiększa elastyczność dla państw członkowskich;

- możliwość opracowania tematycznych pod-programów w ramach PROW ukierunkowanych na wybrane zagadnienia (młodzi rolnicy, małe gospodarstwa, obszary górskie, skrócenie łańcucha dostaw);

- poszerzenie instrumentarium ROW o instrumenty zarządzania ryzykiem w tym o instrument stabilizacji dochodów (zrekompensowanie rolnikowi poważnych strat w dochodach);

— wysoki poziom współfinansowania z EFROW dla kategorii regionów „mniej rozwinięte”.

\section{Wspólna organizacja rynków rolnych}

Negatywne:

- likwidacja kwotowania mleka (od 1 kwietnia 2015 r.) i cukru (do 30 września 2015 r.), przy zapewnieniu możliwości stosowania obowiązkowych umów kontraktacyjnych i negocjowania cen przez organizacje producentów i ich zrzeszenia (mleko) i utrzymanie obowiązku podpisywania porozumień branżowych (cukier);

- zmiana mechanizmu dopłat do prywatnego przechowywania masła z obligatoryjnego na fakultatywny, w rezultacie czego mechanizm nie byłby uruchamiany automatycznie każdego roku, jak to ma miejsce obecnie;

- likwidacja mechanizmu dopłat do odtłuszczonego mleka w proszku, wykorzystywanego w produkcji pasz oraz do mleka odtłuszczonego wykorzystywanego w produkcji kazeiny i kazeinianów oznacza, że nie będzie instrumentów pozwalających na szybką reakcję w przypadku wystąpienia zakłóceń funkcjonowania rynku mleka w zakresie białka mlecznego;

— brak aktualizacji (podniesienia), ze względu na rosnące koszty produkcji, poziomu cen referencyjnych mięsa i zbóż;

- przeniesienie wsparcia organizowania się w grupy producentów sektora owoców i warzyw do II filara i pozostawienie wsparcia organizacji producentów w I filarze komplikuje system wsparcia tego sektora; likwidacja pomocy inwestycyjnej dla grup producentów owoców i warzyw w obecnej wysokości $75 \%$ kosztów kwalifikowanych przy utrzymaniu pomocy administracyjnej (ograniczonej do 5 lat oraz procentowo i kwotowo).

\section{Pozytywne}

- utrzymanie publicznej interwencji i dopłat do prywatnego przechowywania;

- wprowadzenie fakultatywnego mechanizmu dopłat do prywatnego przechowywania odtłuszczonego mleka w proszku; 
— rozszerzenie stosowania: (i) ogólnej klauzuli „kryzysowej” w przypadku ryzyka wystąpienia zakłóceń rynkowych, spowodowanych znacznymi wzrostami/spadkami cen na rynku wewnętrznym lub rynkach zewnętrznych albo innymi czynnikami oraz (ii) mechanizmu wsparcia związanego z utratą zaufania konsumentów, na wszystkie sektory ujęte w obecnej WOR;

- dążenie do wzmocnienia pozycji producentów rolnych w łańcuchu żywnościowym poprzez: (i) rozszerzenie uznawania przez państwa członkowskie organizacji producentów i ich zrzeszeń, jak również organizacji międzybranżowych, na wszystkie sektory ujęte w obecnej WOR; (ii) specjalne podejście do celów WPR oraz producentów rolnych i ich związków w zakresie prawa dotyczącego konkurencji;

— zachęta dla organizacji producentów, ich zrzeszeń i organizacji międzybranżowych do dostosowania podaży do wymogów rynku z wyłączeniem wycofywania produktów z rynku, w odniesieniu do roślin i produktów pochodzenia zwierzęcego (z wyłączeniem mleka).

The Analysis and Assessment of the European Commission's Legislative Package and the Standpoint of the Polish Minister of Agriculture and Rural Development Concerning the Shape of the Common Agricultural Policy of the European Union after 2013

\section{Summary}

The Common Agricultural Policy of the European Union plays a particular role in the process of European integration and the implementation of numerous community goals that go beyond the traditional functions of agriculture, associated with the production of food, and concern the multifunctional development of rural territories. The CAP played the main role in enlarging the EU, by incorporating the twelve new states from Central and Eastern Europe by means of ensuring their smooth integration into the common market and facilitating the accelerated adaptation, modernization and restructurization of the agricultural and food sectors, as well as the non-agricultural fields of the socio-economic and cultural activation of rural populations. The EU's agricultural and rural policy continues to undergo evolutionary transformation, and its shape in the new 2014-202 financial perspective is of vital and justified interest for Poland. The paper presents the latest proposals of the European Commission in this respect, presented on October 12, 2011, the Polish official negotiating position and the author's assessments, opinions and predictions. 
